Benha Veterinary Medical Journal 39 (2020) 184-188

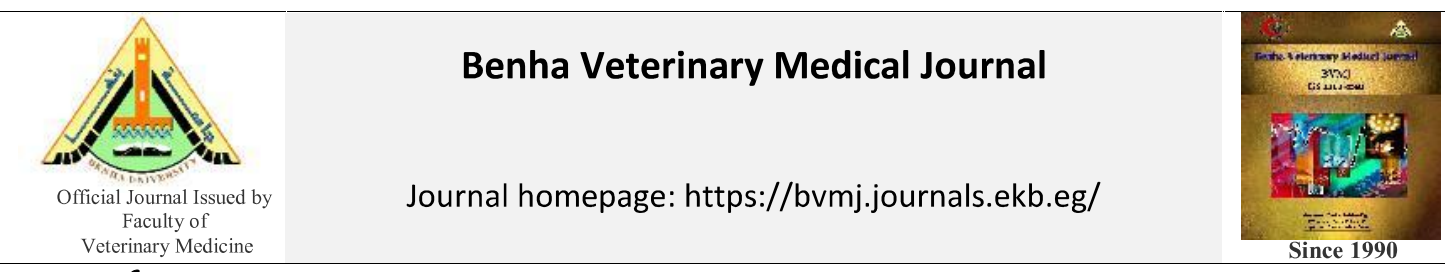

Original Paper

\title{
Assessment of some pathogens in retailed poultry meat
}

\author{
Shimaa Rashad ${ }^{1}$, Amani Salem ${ }^{1}$, Ahmed Maarouf ${ }^{2}$ \\ ${ }^{I}$ Department of Food Control, Faculty of Vet. Med., Benha University, Egypt. \\ ${ }^{2}$ Animal Health Research Institute, "Benha branch "ARC
}

\section{ARTICLE INFO}

\section{Keywords}

Food poisoning

PCR

Poultry meat

SET-RPLA test.

Received 14/03/2020

Accepted 06/07/2020

Available On-Line

$01 / 10 / 2020$

\begin{abstract}
The present study was performed on 150 random samples of Fresh, half cooked (nuggets) and cooked (grilled) chicken meat (50 of each) were purchased from retail chicken butchers, different supermarkets and restaurants in Kaliobia Governorate, Egypt, to evaluate their bacterial quality and safety. Bacteriological examination of chicken meat samples revealed that the mean values of APC, Enterobacteriaceae, Coliform, Staphylococcus and Staph. aureus $\left(\mathrm{cfu} / \mathrm{g}\right.$ ) were $9.88 \times 10^{5} \pm 0.61 \times 10^{5}, 3.36 \times 10^{4} \pm 0.26 \times 10^{4}, 1.43 \times 10^{4} \pm 0.16 \times 10^{4}, 2.71 \times 10^{3} \pm$ $0.17 \times 10^{3}$ and $2.05 \times 10^{3} \pm 0.24 \times 10^{3}$ in fresh, $5.48 \times 10^{4} \pm 0.23 \times 10^{4}, 3.15 \times 10^{2} \pm 0.15 \times 10^{2}$ $1.00 \times 10^{2} \pm 0.08 \times 10^{2}, \quad 1.73 \times 10^{2} \pm 0.11 \times 10^{2}$ and $1.26 \times 10^{2} \pm 0.19 \times 10^{2}$ in half cooked and $4.50 \times 10^{4} \pm 0.22 \times 10^{4}, \quad 2.06 \times 10^{2} \pm 0.13 \times 10^{2}, \quad 1.09 \times 10^{2} \pm 0.10 \times 10^{2}, \quad 1.05 \times 10^{2} \pm 0.09 \times 10^{2}$ and $1.02 \times 10^{2} \pm 0.15 \times 10^{2}$ cooked chicken meat samples, respectively. Moreover, the incidence of E. coli was $14 \%$ in fresh O55: $\mathrm{H} 7(6 \%), \mathrm{O} 125: \mathrm{H} 21(4 \%), \mathrm{O} 111: \mathrm{H} 2(2 \%)$ and $\mathrm{O} 146$ : $\mathrm{H} 21(2 \%), 6 \%$ in half cooked O55: $\mathrm{H} 7(2 \%), \mathrm{O} 125: \mathrm{H} 21(2 \%)$ and $\mathrm{O} 111: \mathrm{H} 2(2 \%)$ and $6 \%$ in cooked chicken meat samples O55: $\mathrm{H} 7(4 \%)$ and $\mathrm{O} 111$ : $\mathrm{H} 2(2 \%)$. Meanwhile, the incidence of Coagulase positive Staph. aureus were $38 \%, 26 \%$ and $20 \%$ in fresh, half cooked and cooked chicken meat samples. According to SET- RPLA test, seven strains out of twelve examined strains were enterotoxigenic. In addition, PCR showed that Staph. aureus enterotoxins sea, seb, sec, sed, see were detected in ten $S$. aureus isolate from samples.
\end{abstract}

\section{INTRODUCTION}

Poultry meat, mainly chicken broilers is one of the most popular food products worldwide because of its easy digestibility; acceptance by the majority of people and solve the problem of the shortage in fresh meat of high price that is not within the reach of large numbers of families with limited income (Biesalski, 2005; Sousa, 2008). Chicken meat often get contamination from different sources starting from defeathering, evisceration and subsequent processing plant (Houf et al., 2002). The bacterial contamination and hygienic measures during poultry meat production can be measured using the aerobic plate count and three Gram - negative indicator groups of Enterobacteriaceae, Coliforms and Escherichia coli biotype 1 , which is the most important indicator for faecal contamination (Paulsen et al., 2006). The most important bacterial pathogens in chicken meat that is responsible for food-borne infections include E. coli, Salmonellae and coagulase positive $S$. aureus (Bhaisare et al., 2014; Noori and Alwan, 2016). E. coli has become recognized as a serious food borne pathogen and has been associated with numerous outbreaks of disease resulting from contaminated meat products (Gi et al., 2009). Moreover, avian strains of $E$. coli show many similarities with human extra intestinal pathogenic E. coli (ExPEC) strains, in that most of the virulence genes they possess and it can be transferred to humans through consumption of contaminated food or food products causing a variety of infections, including bacteremia, urinary tract infections, neonatal meningitis, pneumonia, deep surgical wound infections, endovascular infections, vertebral osteomyelitis, and septicemia (Ewers et al., 2007). Staphylococcus aureus is considered the thirdmost important cause of food-borne disease in the world (Normanno et al., 2007) and the isolates from chicken carcasses showed proteolytic and lipolytic activity at +20 ${ }^{\circ} \mathrm{C}$, causing meat spoilage (Gundogan and Devren, 2005). This pathogen is considered an excellent indicator of thermal processing inefficiency, inadequate hygienic conditions during food production/preparation or inadequate cooling after food preparation and determined the origin of food poisoning (Alexandra et al., 2011; Sasidharan et al., 2011). They produce disease when the bacteria contaminate food, produce some enzymes which are implicated with Staphylococcus invasiveness and many extracellular substances some of which are heat stable enterotoxins that renders the food dangerous even though it appears normal and extensive cooking can be killed the bacteria but the toxins may not be destroyed because most of them are gene based i.e. they can be carried on the plasmid (Prescott et al., 2005). Moreover, most Salmonella strains found on poultry meat are non-host-specific and are considered capable of causing human food poisoning. Salmonellosis (gastroenteritis) is the most common disease in human (Muth, 2009). Therefore, the present study was conducted to throw the light over the assessment of some

* Corresponding author: Prof. Amani Salem, Department of Food Control, Faculty of Vet. Med., Benha University, Egypt. 
pathogens and sanitary status of chicken meat (raw; half cooked and cooked) in Kaliobia Governorate, beside the phenotypic characterization of the isolate; determination of enterotoxin virulent genes in some isolated $S$. aureus strains by using PCR.

\section{MATERIAL AND METHODS}

\subsection{Samples}

Total of 150 random samples (about $250 \mathrm{~g}$ for each) of chicken meat of Fresh, half cooked (nuggets) and cooked (grilled) chicken meat (50 of each) were collected from retail chicken butchers, different supermarkets and restaurants in Kaliobia Governorate.

\subsection{Preparation of samples (APHA,2001):}

Twenty five grams of each sample under examination were taken under aseptic condition to sterile Stomacher bag then $225 \mathrm{ml}$ sterile $0.1 \%$ peptone water were added, the contents were homogenized at Stomacher for 2 minutes, the mixture was allowed to stand for 5 minutes at room temperature the contents were transferred into sterile flask and thoroughly mixed, $1 \mathrm{ml}$ was transferred into separate tube each containing $9 \mathrm{ml}$ sterile $0.1 \%$ peptone water, from which tenth- fold serial dilutions were prepared. The prepared samples were subjected to the following bacteriological examination:

2.3. Aerobic Plate Count $(A P C) / g$, using the standard plate count following FDA (2001).

2.4. Enterobacteriaceae count by the surface plating method of ICMSF (1996) using Violet Red Bile Glucose agar medium (VRBG).

2.5. Coliform count by the surface plating method of ICMSF (1996) using Violet Red Bile agar medium.

2.6. Isolation and identification of E. coli following (ISO 2001).

2.7. Staphylococcus and S. aureus counts (FDA, 2001).

2.8. Isolation and identification of S. aureus (Quinn et al., 2002)

2.9. Isolation and identification of Salmonella (ISO, 2002)

2.10. Detection of Enterotoxins producing $S$. aureus isolates

2.10.1. Detection by Reversed Passive Latex agglutination kit (SET-RPLA) test (Igarashi et al., 1986).

2.10.2. Molecular detection of enterotoxins of some isolated S. aureus strains:

Genotyping detection of enterotoxins A (sea) gene, enterotoxins B (seb) gene, enterotoxins C ( sec) gene enterotoxins D (sed) gene and enterotoxins $\mathrm{E}$ (see) gene in 10 random $S$. aureus strains using uniplex polymerase chain reaction, following QIAamp ${ }^{\circledR}$ DNA Mini Kit instructions (Qiagen, Germany, GmbH), Emerald Amp GT PCR mastermix (Takara, Japan) and 1.5\% agarose gel electrophoreses (Sambrook et al., 1989) using the Primers sequences, target genes, amplicons sizes and cycling conditions.

\subsection{Statistical analysis}

The obtained data were analyzed using the computer software program (SPSS, 2001).

\section{RESULTS}

It is evident from the result recorded in table (1) that the APC and Enterobacteriaceae counts (cfu/g) in the examined samples were $9.88 \times 10^{5} \pm 0.61 \times 10^{5}$ and $3.36 \times 10^{4} \pm 0.26 \times 10^{4}$ in fresh chicken meat samples, $5.48 \times 10^{4} \pm 0.23 \times 10^{4}$ and $3.15 \times 10^{2} \pm 0.15 \times 10^{2}$ in half cooked and $4.50 \times 10^{4} \pm 0.22 \times 10^{4}$ and $2.06 \times 10^{2} \pm 0.13 \times 10^{2}$ in cooked samples. While Coliforms, Staphylococci and $S$. aureus counts (cfu/g) were $1.43 \times 10^{4} \pm 0.16 \times 10^{4}, \quad 2.71 \times 10^{3} \pm 0.17 \times 10^{3}$ and $2.05 \times 10^{3} \pm$ $0.24 \times 10^{3}$ in fresh samples, $1.00 \times 10^{2} \pm 0.08 \times 10^{2}, 1.73 \times 10^{2} \pm$ $0.11 \times 10^{2}$ and $1.26 \times 10^{2} \pm 0.19 \times 10^{2}$ in half cooked and $1.09 \times 10^{2} \pm 0.10 \times 10^{2}, 1.05 \times 10^{2} \pm 0.09 \times 10^{2}$ and $1.02 \times 10^{2} \pm$ $0.15 \times 10^{2}$ in cooked samples, respectively.

From the previous results it's revealed that fresh samples showed a significant increase when compared with half cooked and fried $(\mathrm{P} \leq 0.05)$. Moreover, half cooked showed a significant increase of Enterobacteriaceae and Staphylococci counts when compared with cooked samples. While there is no significant difference of APC, Coliforms and S. aureus counts between half cooked and cooked samples $(\mathrm{P}>0.05)$.

The results in table (1) also showed that the incidence of Enterobacteriaceae, Coliform, E.coli, Staphylococci and $S$. aureus were $100,82,14,100,38 \%$, respectively in fresh samples , 84, 72, 6, 78, $26 \%$ in half cooked and 82, 32, 6, $72,20 \%$, respectively in cooked samples.

Table (2) declared that the incidence and serotyping of Enteropathogenic E. coli isolated from fresh; half cooked and cooked chicken meat samples were O55: $\mathrm{H} 7$ (3, 1 and 2) respectively, O125: H21 (2 from fresh and 1 from each samples half cooked and cooked), O111: H2 (1 from each samples of fresh and half cooked samples only) and O146: H21 (1 from fresh samples only).

Results in table (3) revealed that the percentage of accepted samples for APC, Enterobacteriaceae, Coliform, E.coli, and Staphylococci counts were $100 \%, 0 \%, 18 \%, 86 \%$ and $0 \%$ in fresh samples, $100 \%, 100 \%, 100 \%, 94 \%$ and $100 \%$ in half cooked and cooked samples, respectively, according to the safe permissible limits stipulated by EOS (2005).

The results of SET -RPLA test in table (4) showed that, the incidence of s. aureus enterotoxigenic strains in 12 isolates were $25 \%$ of both of $(A),(B),(C)$, and $(A \& C)$ in fresh, $25 \%$ of (A) and (D) in half cooked and $25 \%$ of (A) in cooked. 7 $(58.3 \%)$ were enterotoxigenic strain.

As shown in table (5) PCR results showed that the incidences of $S$. aureus enterotoxins sea, seb, sec, sed and see were $(25 \%, 25 \%, 25 \%, 25 \%$ and $50 \%)$ in fresh samples, $(33,3 \%, 0 \%, 33,3 \%, 33,3 \%$ and $33,3 \%)$ in half cooked samples and $(33,3 \%, 0 \%, 0 \%, 0 \%$ and $0 \%)$ in cooked samples respectively, With total no $(3,1,2,2$ and $3)$ and incidence $(30 \%, 10 \%, 20 \%, 20 \%$ and $30 \%)$ respectively. Salmonella serovars were failed to be detected in all examined samples of chicken meat.

\section{DISCUSSION}

Poultry meat mainly chicken is a common vehicle for pathogenic microorganisms. These pathogens are transmitted mainly through consumption of contaminated food and the presence of these organisms in meat has relevant public health implications (Bhaisare et al., 2014; Darshana et al., 2014).

The data shown in table (1) revealed that, APC was higher in fresh samples than half cooked and cooked chicken meat samples. It may be due to insufficient heating or postcooking contamination that may be due to lack of hygienic measure in handling of chicken meat.

According to our results of APC, nearly similar results in fresh samples were obtained by Mohamed (2016) 
$\left(3.78 \times 10^{6} \pm 0.93 \times 10^{6}\right)$, but higher than that reported by Daoud $(2012)\left(2.1 \times 10^{3}\right)$, lower than that reported by Vural et al. (2006) $\left(1.48 \times 10^{7}\right)$. The results in half cooked and cooked chicken meat samples were nearly similar to that recorded by Arab (2010) $\left(6.3 \times 10^{4} \pm 0.35 \times 10^{4}\right)$, but higher than that reported by El-Taher (2009) $\left(9.05 \times 10^{3} \pm 2.51\right.$ $\times 10^{3}$ ), meanwhile, they were lower than that recorded by Kirralla (2007) $\left(2.20 \times 10^{6} \pm 2.12 \times 10^{5}\right)$

Moreover, table (1) showed that Enterobacteriaceae was higher in fresh samples than half cooked and cooked samples. this may explain the fact that the GIT

is common habitat of Enterobacteriacae and is considered the main source of contamination during slaughtering, dressing, evisceration, handling and transportation to butcher shops.

Enterobacteriaceae count in fresh samples nearly similar to that obtained by Marwan $(2016)\left(3.37 \times 10^{4} \pm 0.23 \times 10^{4}\right)$, but higher than that reported by Ibrahim (2005) $(6.72 \pm 1.09 \mathrm{x}$ 10). Meanwhile, the results of half cooked and cooked chicken meat samples were agreed with those of Marwan (2016) $\left(0.92 \times 10^{2} \pm 0.08 \times 10^{2}\right)$ but disagree with those of Abd El-Aal (2015) $\left(8.73 \times 10^{3} \pm 1.96 \times 10^{3}\right)$.

Results achieved in table (1) illustrated that Coliform count was higher in fresh samples than half cooked and cooked samples. This may be attributed to higher contamination from the ground and fecal matter.

Table 1 Mean values of microbial counts (cfu/g) and their Incidence in the examined chicken meat samples ( $\mathrm{n}-50)$.

Isolates Fresh samples Half cooked samples

\begin{tabular}{|c|c|c|c|c|c|c|c|c|}
\hline \multicolumn{3}{|c|}{ Fresh samples } & \multicolumn{3}{|c|}{ Half cooked samples } & \multicolumn{3}{|c|}{ Cooked samples } \\
\hline \multicolumn{2}{|c|}{ +ve samples } & \multirow[t]{2}{*}{ Mean \pm SE** } & \multicolumn{2}{|c|}{ +ve samples } & \multirow[t]{2}{*}{ Mean \pm SE** $^{* *}$} & \multicolumn{2}{|c|}{ +ve samples } & \multirow[t]{2}{*}{ Mean \pm SE** $^{* *}$} \\
\hline No. & $\% *$ & & No. & $\% *$ & & No. & $\% *$ & \\
\hline- & - & $9.88 \times 10^{5} \pm 0.61 \times 10^{5}$ & - & - & $5.48 \times 10^{4} \pm 0.23 \times 10^{4}$ & - & - & $4.50 \times 10^{4} \pm 0.22 \times 10^{4}$ \\
\hline 50 & 100 & $3.36 \times 10^{4} \pm 0.26 \times 10^{4}$ & 42 & 84 & $3.15 \times 10^{2} \pm 0.15 \times 10^{2}$ & 41 & 82 & $2.06 \times 10^{2} \quad \pm 0.13 \times 10^{2}$ \\
\hline 41 & 82 & $1.43 \times 10^{4} \pm 0.16 \times 10^{4}$ & 36 & 72 & $1.00 \times 10^{2} \pm 0.08 \times 10^{2}$ & 16 & 32 & $1.09 \times 10^{2} \pm 0.10 \times 10^{2}$ \\
\hline 50 & 100 & $2.71 \times 10^{3} \pm 0.17 \times 10^{3}$ & 39 & 78 & $1.73 \times 10^{2} \pm 0.11 \times 10^{2}$ & 36 & 72 & $1.05 \times 10^{2} \pm 0.09 \times 10^{2}$ \\
\hline 19 & 38 & $2.05 \times 10^{3} \pm 0.24 \times 10^{3}$ & 13 & 26 & $1.26 \times 10^{2} \pm 0.19 \times 10^{2}$ & 10 & 20 & $1.02 \times 10^{2} \pm 0.15 \times 10^{2}$ \\
\hline 19 & 38 & - & 13 & 26 & - & 10 & 20 & - \\
\hline
\end{tabular}

Coagulase Positive $S$. aureus

* Percentage in relation to total number of samples in each row (50). **Standard error

Table 2 Incidence and serotyping of $E$. coli isolated from positive samples of chicken meat ( $\mathrm{n}=50$ of each)

\begin{tabular}{|c|c|c|c|c|c|c|c|}
\hline \multirow[b]{2}{*}{ E. coli serotype } & \multicolumn{2}{|c|}{ Fresh chicken meat } & \multicolumn{2}{|c|}{ Half cooked chicken meat } & \multicolumn{2}{|c|}{$\begin{array}{c}\text { Cooked } \\
\text { chicken meat }\end{array}$} & \multirow[b]{2}{*}{$\begin{array}{c}\text { Strain } \\
\text { characteristic }\end{array}$} \\
\hline & No. & $\% *$ & No. & $\% *$ & $\begin{array}{l}\mathrm{cl} \\
\text { No. }\end{array}$ & $\begin{array}{l}\text { at } \\
\% *\end{array}$ & \\
\hline $\mathrm{O} 55: \mathrm{H} 7$ & 3 & 6.0 & 1 & 2.0 & 2 & 4.0 & EPEC \\
\hline $\mathrm{O} 111: \mathrm{H} 2$ & 1 & 2.0 & 1 & 2.0 & 0 & 0.0 & EHEC \\
\hline $\mathrm{O} 125: \mathrm{H} 21$ & 2 & 4.0 & 1 & 2.0 & 1 & 2.0 & ETEC \\
\hline $\mathrm{O} 146: \mathrm{H} 21$ & 1 & 2.0 & 0 & 0.0 & 0 & 0.0 & EPEC \\
\hline Total & 7 & 14.0 & 3 & 6.0 & 3 & 6.0 & - \\
\hline
\end{tabular}

$* \%$ was calculated in relation to total number of each sample (50). EPEC: Enteropathogenic $E$. coli. ETEC: Enterotoxigenic E. coli. EHEC= Enterohaemorrhagic $E$. coli

Table 3 Acceptability of examined chicken meat samples according to EOS (2005). $(n=50)$ for each.

\begin{tabular}{|c|c|c|c|c|c|c|c|c|c|}
\hline & \multicolumn{9}{|c|}{ Accepted Samples } \\
\hline & \multicolumn{3}{|c|}{ Fresh chicken meat } & \multicolumn{3}{|c|}{ Half cooked chicken meat } & \multicolumn{3}{|c|}{ Cooked chicken meat } \\
\hline & P.L/g* & No. & $\% *$ & P.L/g* & No. & $\% *$ & P.L $/ \mathrm{g}^{*}$ & No. & $\% *$ \\
\hline $\mathrm{APC}$ & $\geq 10^{5}$ & 50 & 100 & $\geq 10^{4}$ & 50 & 100 & $\geq 10^{4}$ & 50 & 100 \\
\hline Enterobacteriaceae & $\leq 10^{2}$ & 0 & 0 & $\leq 10^{2}$ & 50 & 100 & $\leq 10^{2}$ & 50 & 100 \\
\hline Coliform & $\leq 10^{2}$ & 9 & 18 & $\leq 10^{2}$ & 50 & 100 & $\leq 10^{2}$ & 50 & 100 \\
\hline e. coli & $\leq 10^{2}$ & 43 & 86 & $\leq 10^{2}$ & 47 & 94 & $\leq 10^{2}$ & 47 & 94 \\
\hline Staphylococci & $\leq 10^{2}$ & 0 & 0 & $\leq 10^{2}$ & 50 & 100 & $\leq 10^{2}$ & 50 & 100 \\
\hline
\end{tabular}

Table 4 The incidence of enterotoxins production from (12) S. aureus isolates 4 from each according to SET -RPLA test

\begin{tabular}{|c|c|c|c|c|c|c|c|c|c|c|}
\hline \multirow[t]{2}{*}{ Samples } & \multicolumn{2}{|c|}{ A } & \multicolumn{2}{|c|}{ B } & \multicolumn{2}{|c|}{ C } & \multicolumn{2}{|c|}{ D } & \multicolumn{2}{|c|}{ A\&C } \\
\hline & No. & $\%$ & No. & $\%$ & No. & $\%$ & No. & $\%$ & No. & $\%$ \\
\hline Fresh & 1 & 25 & 1 & 25 & 1 & 25 & - & - & 1 & 25 \\
\hline Half cooked & 1 & 25 & - & - & - & - & 1 & 25 & - & - \\
\hline Cooked & 1 & 25 & - & - & - & - & - & - & - & - \\
\hline Total no. & \multicolumn{2}{|c|}{3} & \multicolumn{2}{|c|}{1} & \multicolumn{2}{|c|}{1} & \multicolumn{2}{|c|}{1} & \multicolumn{2}{|c|}{1} \\
\hline$\%$ & \multicolumn{2}{|c|}{25} & \multicolumn{2}{|c|}{8.3} & \multicolumn{2}{|c|}{8.3} & \multicolumn{2}{|c|}{8.3} & \multicolumn{2}{|c|}{8.3} \\
\hline
\end{tabular}

Table 5 The results of PCR amplifications of different used enterotoxins genes of $S$. aureus.
No

\begin{tabular}{|c|c|c|c|c|c|c|c|c|c|c|c|}
\hline \multirow[t]{2}{*}{ Samples } & \multirow[t]{2}{*}{ No. } & \multicolumn{2}{|c|}{ Sea } & \multicolumn{2}{|c|}{$S e b$} & \multicolumn{2}{|c|}{$\mathrm{Sec}$} & \multicolumn{2}{|c|}{ Sed } & \multicolumn{2}{|c|}{ See } \\
\hline & & No. & $\%$ & No. & $\%$ & No. & $\%$ & No. & $\%$ & No. & $\%$ \\
\hline Fresh & 4 & 1 & 25 & 1 & 25 & 1 & 25 & 1 & 25 & 2 & 50 \\
\hline Half cooked & 3 & 1 & 33.3 & - & - & 1 & 33.3 & 1 & 33.3 & 1 & 33.3 \\
\hline Cooked & 3 & 1 & 33.3 & - & - & - & - & - & - & - & - \\
\hline Total no. & & \multicolumn{2}{|c|}{3} & \multicolumn{2}{|c|}{1} & \multicolumn{2}{|c|}{2} & \multicolumn{2}{|c|}{2} & \multicolumn{2}{|c|}{3} \\
\hline$\%$ & & \multicolumn{2}{|c|}{30} & \multicolumn{2}{|c|}{10} & \multicolumn{2}{|c|}{20} & \multicolumn{2}{|c|}{20} & \multicolumn{2}{|c|}{30} \\
\hline
\end{tabular}

$\operatorname{sea}($ enterotoxin A). seb (enterotoxin B). sec (enterotoxin C). sed (enterotoxin D. see (enterotoxin E) 
Coliform counts were low in half cooked and fried chicken meat, this may be due to the hygienic preparation and the attained temperature for both cooking and frying was sufficient to kill vegetative bacteria on the surface of meat. Coliforms count in fresh samples came in parallel with those of Marwan $(2016)\left(1.35 \times 10^{4} \pm 0.08 \times 10^{4}\right)$ but disagree with that reported by Hassan $(2015)\left(1.7 \times 10^{3} \pm 1.5 \times 10^{2}\right)$ and Mohamed (2016) $\left(2.07 \times 10^{3} \pm 0.60 \times 10^{3}\right)$. Meanwhile, the results in half cooked and cooked chicken meat samples were nearly similar to that recorded by Marwan (2016) $\left(0.25 \times 10^{2} \pm 0.04 \times 10^{2}\right)$, but disagree with that reported by Ibrahim et al. (2014) $\left(1.18 \times 10^{3} \pm 0.26 \times 10^{3}\right)$ and Abd El-Aal (2015) $\left(6.40 \times 10^{3} \pm 1.23 \times 10^{3}\right)$

Table (1) showed also that, Staphylococci count was higher in fresh than half cooked and cooked samples, It may be due to it considered as a part of normal flora that found on the skin and upper respiratory tract of animal and man, because their ubiquitous occurrence in nature, they were found in various raw foods.

According to Staphylococci count was nearly similar to the results obtained by Ruban and Fairoze (2011) $\left(5.5 \times 10^{3} \pm\right.$ $0.12 \times 10^{3}$ ) but disagree with that reported by Hassan (2015) $\left(2.5 \times 10^{5} \pm 4.2 \times 10^{4}\right)$ and Marwan (2016) $\left(1.73 \times 10^{4}\right.$ $\left.\pm 0.09 \times 10^{4}\right)$. Meanwhile, the results in half cooked and cooked chicken meat samples were similar to that recorded by Marwan $(2016)\left(0.80 \times 10^{2} \pm 0.04 \times 10^{2}\right)$ but disagree with that reported by Abd El-Aal- $(2015)\left(2.10 \times 10^{3} \pm 0.32 \times 10^{3}\right)$.

In addition, table (1) revealed that, $S$. aureus count was higher in fresh than half cooked and cooked samples. It is commonly indicate a direct contamination from worker's hands with abrasion and wounds or inadequately cleaned equipment resulting in $S$. aureus intoxication. Staphylococcal food poisoning is the result of performed enterotoxins that are produced by certain strains of $S$. aureus resulting in symptoms of intoxication.

The results of $S$. aureus count in fresh samples agree with those of Mahmoud and Hamouda (2006) $\left(8.9 \times 10^{3} \pm\right.$ $0.3 \times 10^{3}$ ) but disagree with that reported by Mohamed (2016) $\left(1.12 \times 10^{4} \pm 0.83 \times 10^{3}\right)$. Meanwhile, the results in half cooked and cooked chicken meat samples was disagreed with that reported by Ibrahim (2005), who reported that no detectable level of $S$. aureus was obtained.

While incidence of Coagulase Positive $S$. aureus in table (1) go in parallel with this obtained by Abd Allah (2017). but, disagreed with those of Ahmed (2015) and Olukemi et al. (2015), who isolated $S$. aureus with higher incidence. Also, disagreed with Osman et al. (2016), who isolated $S$. aureus with lower incidence and with Ibrahim (2005) who failed to isolated $S$. aureus from cooked chicken meat samples.

The recorded results in table (2) showed that, the incidence of $E$. coli was higher in fresh samples than half cooked and cooked. Moreover, it may be due to mishandling during production, processing and distribution Kagambega et al. (2012). The pathogenic strains of $E$. coli can cause distinct disease syndrome as different diarrheal diseases, wound infections, meningitis, septicemia, atherosclerosis, hemolytic uremic syndrome and immunological diseases such as reactive and rheumatoid arthritis.

These results and the same serotypes of $E$. coli were previously isolated from both fresh and cooked chicken meat, came in accordance with those obtained by Marwan (2016) and Abd El-Alim (2017). Meanwhile, disagree with those of Abbass (2011), who failed to isolate E. coli form chicken meat samples.
Moreover, results in table (3) revealed that, the acceptable samples of fresh samples were lower than that of half cooked and cooked ones. This may be due to that chicken meat may be contaminated by infected handlers during slaughter and processing of livestock or by crosscontamination during food preparation.

The results of SET -RPLA test recorded in table (4) were nearly similar to that recorded by Abdalrahman et al. (2015) and El-sayed (2015).

Regarding to the results of PCR listed in table (5) the incidence of sea and see genes were higher than incidence of sec and Sed genes, followed by seb.

Nearly similar results of sea gene obtained by Abdalrahman et al. (2015) and Abd Allah (2017). Meanwhile, the results were disagreed with FeBler et al. (2011), who failed to detect sea gene in $S$. aureus strains isolated from poultry products. Also, the results of seb gene, nearly similar to those obtained by Abdalrahman et al. (2015) and Abd Allah (2017). In addition, the results of $\mathrm{sec}$ gene, nearly similar to those obtained by Madahi et al. (2014). Meanwhile, the results of sed gene, agree with those obtained by Abdalrahman et al. (2015) and Abd Allah (2017). Moreover, the results of see gene come in parallel with those obtained by Mostafa (2014).

\section{CONCULSION}

The present study concluded that, chicken meat (fresh, half cooked and cooked) were subjected to various degree of bacterial contamination. Consequently, fresh samples were the most contaminated ones. Therefore, a concerted effort should be made to maintain sanitary condition and strict maintenance of good practices of hygiene in all processing to ensure meat quality and safety.

\section{REFERENCES}

1. Abbass, O. M. 2011. Evaluation of the HACCP system in the restaurants of the tourism sector. M. V. Sc. Thesis, (Meat Hygiene), Fac. Vet. Med. Benha University.

2. AbdAllah, R. N. 2017. Detection of virulent genes responsible for Staphylococcus aureus enterotoxins production in chicken meat using PCR. Ph. Sc. Thesis, Meat Hygiene, Fac. Vet. Med., Benha Univ.

3. Abd El- Alim H.A. 2017. Bacteriological studies on some bacteria isolated from flesh of imported and local frozen poultry. M.V. Sc. Thesis, (Bacteriology, Immunology and Mycology), Fac. of Vet. Med., Benha Univ.

4. Abd El-Aal, A. M.A. 2015. Bacteriological studies on food meals in governmental hospital. Thesis M. V. Sc. (Meat Hygiene), Fac. Vet. Med. Benha University.

5. Abdalrahman, L. S.; Stanley, A.; Wells, H. and Fakhr, M. K. 2015. Isolation, virulence, and antimicrobial resistance of methicillin-resistant Staphylococcus aureus (MRSA) and methicillin sensitive Staphylococcus aureus (MSSA) Strains from Oklahoma retail poultry meats. Int. J. Environ. Res. Public Health, 12: 6148-6161.

6. Ahmed, H.R. 2015. Isolation and identification of methicillin-resistant $S$. aureus (MRSA) from poultry meat and poultry products.Kafr el-sheikh Vet. Med. J.,13(1): 5769.

7. Alexandra, F.; Britta, K.; Gladys, K.; Beatriz, G.R.; Katja, A.; Hammerl, J.A.; Annemarie, K.; Juliane, B.; Bernd, A and Bernd-Alois, T. 2011. Methicillin susceptible and resistant Staphylococcus aureus from farm to fork impact on food safety Tehnologiimesa, 52 (1): 60-65. 
8. APHA "American Public Health Association" 2001. "Compendium of Methods for the Microbiological examination of Foods". $4^{\text {th }}$ Ed. F.P. Downes and K. Ito(editors), APHA. Washington D.C., USA.

9. Arab, W. S. 2010. Quality improvement of meat meals provided by a university student restaurant. Ph.D. Thesis (Meat Hygiene), Fac. Vet. Med. Benha University.

10. Assèta Kagambèga, Outi Martikainen , Taru Lienemann Anja Siitonen, Alfred S.Traoré, Nicolas Barro, Kaisa Haukka 2012. Diarrheagenic Escherichia coli detected by 16-plex PCR in raw meat and beef intestines sold at local markets in Ouagadougou, Burkina Faso. International Journal of Food Microbiology 153 (1-2): 154-158.

11. Biesalski, H. K. 2005. Meat as a component of a healthy diet. Are there any risks or benefits if meat is avoided in the diet. Meat Science, 70: 509-524.

12. Daoud. J. R. 2012. Microbial quality of frozen chicken meat at grocery stores in Qena city, International Conference and Exhibition on Food Processing \& Technology, November 22-24, Hyderabad International Convention Centre, India.

13. Darshana, B. Bhaisare; Thyagarajan, D.; Churchil, R.R.and Punniamurthy, N. 2014. Bacterial Pathogens in Chicken Meat Review. International Journal of Life Sciences Research, 2 (3): 1-7.

14. El-Sayed, A.M. 2015. Prevalence of some food born bacteria isolated from meat and meat products in Kaliubiya Governorate. M. V. Sc. Thesis (Bacteriology), Fac. Vet. Med., Benha Univ.

15. El-Taher, $A$. M. 2009. Impact of temperature abuse on safety of food offered in University Student Restaurant. M.V. Sc. Thesis, Meat Hygiene, Fac. Vet. Med., Benha Univ.

16. Ewers, C.; Li, G.; Wilking-Kiessling, S.; Alt, K. and Antao, E. M. 2007. Avian pathogenic, Uropathogenic, and newborn meningitis-causing Escherichia coli: how closely related are they?. Int. J. Med. Microbiol., 297:163-176.

17. Food and Drug Administration "FDA" 2001. Foodborne illness, what consumer need to know. USDA Food Safety and Inspection Service.

18. Gi Yun Lee, Hye In Jang; In Gyun Hwang; Min Suk Rhee 2009 Prevalence and classification of pathogenic Escherichia coli isolated from fresh beef, poultry, and pork in Korea. International Journal of Food Microbiology 134 (3): 196-200.

19. Gundogan, N.; Citak, S.; Yucel, N. and Devren, A. 2005. A note on the incidence and antibiotic resistance of Staphylococcus aureus isolated from meat and chicken samples. Meat Sci. 69: 807 -810.

20. Hassan, O. 2015. Microbiological status of poultry carcasses from retailed outlets in Alexandria province. M. V. Sc., Thesis, Fac. Vet. Med., Alex. Univ.

21. Houf, K., De Zutter, L., Verbeke, B., Van Hoof, J., Vandamme, P. 2002. Occurrence and distribution of Arcobacter species in poultry processing J Food Prot., 65(8):1233-9-369.

22. Ibrahim, G.M.M. 2005. Controlling microbial contamination of broiler carcasses during processing in Assiut student Universities Restaurants. Ph.D., Fac. Vet. Med., Assiut Univ. Ibrahim, H. M.; Amin-Reham, A. and Sobieh, A. S. 2014. Bacteriological evaluation of fast foods at restaurants level in Cairo governorate.BenhaVet.Med.J.,26 (1):34-42.

23. Igarashi, H.; Fujikawa, H.; Shingaki, M. and Brggdoll, M.S. 1986. Latex agglutination test for staphylococcus toxin shock syndrome toxin 1. J. Clin. Microbiol., 23: 516-521.

24. International Commission on Microbiological Specification for Foods "ICMSF" 1996. Microbiological ecology of food.Vol.1: Factors affecting life and death of microorganisms. $2^{\text {nd }}$ Ed., Academic press, New York, USA.

25. ISO International Organization of Standardization 2001. Microbiology of food and animal feeding stuffs. Horizontal method for the enumeration of $\beta$ - glucuronidase- Positive $E$ Coli. Part 2: Colony- Count technique at $44^{\circ} \mathrm{c}$ using 5 bromo-4-chloro-3- indolyl $\beta$-D-glucuronide.16649-2.

26. ISO International Organization of Standardization 2002. International Organization for Standardization. No.6579. Microbiology of food and animal feeding stuffs - Horizontal methods for detection of salmonella species Kaliobia Government. M.S. Thesis (Meat Hygiene) Fac. Vet. Med., Benha Univ.

27. Kirralla, G.A. 2007. Sanitary status of meat meals of students of Tanta university. M.V. Sc. Thesis (Meat Hygiene), Fac. Vet. Med., Kafr El Sheikh University.

28. Madahi, H.; Rostami,F. ; Rahimi,E.and Dehkordi,F.S. 2014 Prevalence of Enterotoxigenic Staphylococcus aureus Isolated from Chicken Nugget in Iran. Jundishapur J Microbiol., 7(8): 1- 6 .

29. Marwan, Heba, A.I. (2016): Sanitary status of meat meals at hospital level in Kaliobia Governorate. M.V. Sc. Thesis , Fac. Vet. Med., Benha Univ.

30. Mahmoud, Y.EL. and Seham Hamouda, N. 2006. Quality evaluation of poultry meat carcasses in El-Gharbia Governorate markets. Assiut Vet. J. 52(110):31

31. Mohamed, M.S.E.R 2016. Frozen chicken meat Quality in governmental hospital. M.V. Sc. Thesis, Meat Hygiene, Fac. Vet. Med., Benha Univ.

32. Muth, M.K. 2009. Analysis of salmonella control performance in U.S young chicken slaughter and pork slaughter establishments, journal of food protects. 72 (1): 6 13

33. Nemati, M. 2014. Prevalence of Enterotoxin Genes in Poultry Staphylococcus aureus Isolates. Bull. Env. Pharmacol. Life Sci., 3 (2) 14-18.

34. Noori, T.E. and Alwan, M. J. 2016. Isolation and Identification of Zoonotic Bacteria from Poultry Meat. Int. J. Adv. Res. Biol. Sci., 3(8): 57-66.

35. Normanno, G.; La Salandra, G.; Dambrosio, A.; Quaglia, N.C. ; Corrente, M.; Parisi, A.; Santagada, G.; Firin, U. A.; Crisetti, E. and Celano, G. V. 2007."Occurrence, characterization and antimicrobial resistance of enterotoxigenic Staphylococcus aureus isolated from meat and dairy products". International J. Food Microbiology, 115: 290-296.

36. Olukemi, A. Y.; Osas, I. M.; Olaitan, J. O.\& Jeremiah, O, I 2015. Bacterial Contamination Associated with Retail Chicken Carcasses in Osogbo, Nigeria, Nitte University Journal of Health Science (NUJHS). 5(4): 45-50.

37. Osman, K.; Badr, J.; Al-Maary, K. S.; Moussa, I. M.I. Hessain, A. M.; Girah, Z. M.S.A.; Abo-shama, U.H. and Orabi,A. 2016. Prevalence of the Antibiotic Resistance Genes in Coagulase-Positive- and Negative-Staphylococcus in Chicken Meat Retailed to Consumers. frontiers in microbiology vol.7: 1-12. Article 1846.

38. Paulsen, P.; Schopf, E. and Smulders, F. J. M. 2006 Enumeration of total aerobic bacteria and $E$. coli in minced meat and on carcass surface samples with an automated most-probable-number method compared with colony count protocols. J. Food Prot., 69(10): 2500 - 2503.

39. Prescott, L.M., Harley, J.P and Klein, D.A 2005. Microbiology Le Loir Y, Baron F, Gautier M. Staphylococcus aureus and food poisoning. Genet Mol Res 2003; 2:63-76.

40. Quinn, P. J., Markey, B. K., Carter, M. E., Donnelly, W. J. C., Leonard, F. C. and Maguire, D. 2002. "Veterinary microbiology and microbial disease". Iowa State Univ. Press, Blackwell Science Ltd, chapters 26-36: 84-96.

41. Ruban, S.W. and Fairoze, N 2011. Effect of processing condition on microbiological quality of market poultry meats in Bangalore, Ind. J. Ani. Vet. Adv., 10(2):188-191.

42. Sambrook, J.; Fritsch, E.F. and Montias, T. 1989. Molecular Biology. In: Molecular cloning. Laboratory manual, Second Edition. Cold Spring Harbor Laboratory press, USA

43. Sasidharan, S.; Prema, B. and Yoga Ltha, L. 2011. Antimicrobial drug resistance of Staphylococcus aureus in dairy products. Asian Pacific Journal of Tropical Biomedicine: 130-132

44. Sousa, C. P. 2008. "The Impact of Food Manufacturing Practices on Food borne Diseases". Brazilian Archives of Biology and Technology, 51(4), 815-823.

45. SPSS for windows, Version 11. Copyright SPSS Inc. 19892001. All rights reserved.

46. Vural, A.; Erkan, M. and Yesilmen, S. 2006. Microbiological quality of retail chicken carcasses and their products in Turkey. Medyna Wet., 62, 1371-1374. 